\title{
Temporal coherence of physical, chemical and biological variables in four tropical lakes (Minas Gerais, Brazil)
}

\author{
Coerência temporal de variáveis físicas, químicas e biológicas em quatro lagos tropicais \\ (Minas Gerais, Brasil)
}

Mariana Peifer Bezerra ${ }^{1}$, Pedro Maia Barbosa ${ }^{2}$, Francisco Antônio Rodrigues Barbosa ${ }^{1}$ and José Fernandes Bezerra Neto ${ }^{1 *}$

${ }^{1}$ Laboratório de Limnologia, Ecotoxicologia e Ecologia Aquática - LIMNEA, Instituto de Ciências Biológicas - ICB, Universidade Federal de Minas Gerais - UFMG, Av. Antônio Carlos, 6627, Pampulha, CEP 30270-901, Belo Horizonte, MG, Brazil

${ }^{2}$ Laboratório de Limnologia, Universidade Federal do Rio de Janeiro - UFRJ, Av. Carlos Chagas Luz, 373, Edifício CCS, Bloco A, Cidade Universitária, Ilha do Fundão, RJ, Brazil

*e-mail: joseneto@icb.ufmg.br

Cite as: Bezerra, M.P. et al. Temporal coherence of physical, chemical and biological variables in four tropical lakes (Minas Gerais, Brazil). Acta Limnologica Brasiliensia, 2017, vol. 29, e12.

\begin{abstract}
Aim: The main objective of this study was to evaluate the presence of temporal coherence of limnological variables and pairs of lakes considering four tropical lakes of the Rio Doce State Park, using monthly data from the Long-Term Ecological Research Program (LTER) between the years of 2004 to 2009. Methods: Subsurface data (0.5 meters) from the Carioca, Dom Helvécio, Gambazinho, and Jacaré Lakes were used in the analysis. We estimated the temporal coherence from the creation of time series for each of the variables. Through these series, we calculated the Pearson correlation coefficient between all pairs of lakes $(\mathrm{N}=6)$ and performed the average. We also analyzed the correlation between the temporal coherence found for the different pairs of lakes and two predictors of spatial patterns: proximity and exposure to climatic factors. The spatial proximity of the lake pairs was calculated in kilometers, and the exposure to climatic factors was estimated using two metrics: surface area and surface area/mean depth ratio. Results: The largest temporal coherence levels were recorded for water temperature (0.97), $\mathrm{pH}$ (0.78), and dissolved organic carbon (DOC) (0.74). The lowest levels were found for chlorophyll-a $(0.25)$ and phytoplankton richness $(-0.02)$. The average temporal coherence was 0.58 . Different from other studies, no significant correlation was found between the synchronicity of the lake pairs and the differences in their exposure to climatic factors. Also, no relation was found with the spatial proximity. Conclusions: Our results demonstrate the existence of temporal coherence in tropical lakes to compatible levels with those found in temperate regions. Our work contributes to the knowledge of how synchronicity works at different set of lakes and climatic regions.
\end{abstract}

Keywords: synchronicity; temporal coherence; spatial heterogeneity; tropical lakes.

Resumo: Objetivo: Este estudo teve como objetivo principal avaliar a presença de coerência temporal de variáveis limnológicas e pares de lagos para quatro lagos tropicais da região do Parque Estadual do Rio Doce, utilizando dados mensais do Programa de Pesquisas Ecológicas de Longa Duração (PELD) entre os anos de 2004 a 2009. Metodologia: Dados de sub-superfície (0,5 metro) das lagoas Carioca, Dom Helvécio, Gambazinho e Jacaré foram utilizados nas análises. Nós estimamos a coerência temporal a partir da criação de séries temporais para cada uma das variáveis. Por meio 
dessas séries, foi calculado o coeficiente de correlaçáo de Pearson entre todos os pares de lagos $(\mathrm{N}=6)$ e realizado a média. Nós também analisamos a correlação entre a coerência temporal encontrada para os diferentes pares de lagos e dois preditores de padróes espaciais: proximidade e exposição a fatores climáticos. A proximidade espacial dos pares de lagos foi calculada em quilômetros e a exposição a fatores climáticos foi estimada utilizando duas métricas: área superficial e área superficial / profundidade média. Resultados: Os maiores níveis de coerência temporal foram registrados para temperatura da água $(0,97), \mathrm{pH}(0,78)$ e carbono orgânico dissolvido (COD) (0,74). Já os menores níveis foram verificados para clorofila-a $(0,25)$ e riqueza fitoplanctônica $(-0,02)$. A coerência temporal média foi de 0,58 . Diferente de outros estudos, não foi encontrado uma correlaçáo significativa entre as sincronicidades dos pares de lagos e as diferenças de suas exposiçóes a fatores climáticos. Além disso, nenhuma relação foi encontrada com a proximidade espacial. Conclusóes: Nossos resultados demonstram a existência de coerência temporal em lagos tropicais a níveis compatíveis com aquelas encontradas em regiôes temperadas. Nosso trabalho contribui para o conhecimento de como a sincronicidade funciona em diferentes conjuntos de lagos e regióes climáticas.

Palavras-chave: sincronicidade; coerência temporal; heterogeneidade espacial; lagos tropicais.

\section{Introduction}

Traditionally within the limnological literature, lakes have been studied in a temporarily restricted manner (Livingstone et al., 2010). For a few decades now, limnologists have become more interested in the study of lakes in a regional context (Magnuson et al., 1990). Thus, lakes started to be analyzed as dynamic and connected systems, instead of spatially independent entities (Baines et al., 2000; Caliman et al., 2010). Nevertheless, it is still a challenge to connect time and space in the study of lakes (Magnuson et al., 2004).

One of the main scientific challenges of this new approach in limnology was the creation of concepts including multiple lakes and longer time scales. The temporal coherence, i.e. the degree in which different systems existing in the same geographical area behave similarly or synchronously over time (Magnuson et al., 1990), was one of the concepts created and enables the identification of patterns within a set of lakes as well as the forces that influence their dynamics. The perception of synchronicity is the first step for possible generalizations regarding regional responses to changes in the climate and the land use (Baines et al., 2000).

The application of predictive models based on temporally synchronic characteristics can be wide. For example, the presence of temporally synchronous features is a prerequisite for monitoring and conservation of lakes in countries of North America and Europe (e.g. Swedish long-term surface water monitoring program). In these countries, in some regions rich in lacustrine environments, the ecological status of waters is investigated from a random sample under the assumption of the presence of reference lakes from the temporal coherence analysis (Folster et al., 2014).
Conceptually, climatic factors act as signals, transmitting its dynamics to the lakes within a particular region. The lake itself would be a receptor composed with filters that can modify the climatic signal according to the morphometry and hydrology present (Magnuson et al., 2004). Therefore, the extrinsic factors (e.g. weather and wind) operate on large spatial scales and have a homogenizing trend in a set of lakes making them more synchronic in their properties (Baines et al., 2000). In contrast, the intrinsic factors such as morphometry, surface area, species composition, and land use induce a more idiosyncratic behavior and may lead to lower temporal coherence (Caliman et al., 2010).

Physical variables (e.g. water temperature) tend to be highly synchronous in a set of lakes, for being typically more influenced by extrinsic factors. In opposition, biological parameters frequently tend to lower coherence values due to its dependence on both local forces and ecological interactions. In contrast, variations in results about temporal coherence of chemical variables lead to different conclusions among researchers, in particular for carbon and nutrients (Magnuson et al., 1990; Kratz et al., 1998; Kling et al., 2000; Pace \& Cole, 2002; Zhang et al., 2010). The concentrations of theses variables depend on an intricate balance between extrinsic and intrinsic influences of the lakes. Previous studies demonstrate that lakes with similar sizes tend to be more coherent about its variables since size can represent a greater or lesser exposure to climatic factors (Magnuson et al., 1990; Kratz et al., 1998). The synchronous behavior of lake pairs can also be related to the proximity of the lakes especially between systems that are connected, as verified by Kling et al. (2000), and Lansac-Tôha et al. (2008). 
Most of the studies about temporal coherence were carried out in temperate regions, with only a few studies in the tropics (Lansac-Tôha et al., 2008; Caliman et al., 2010; Carneiro et al., 2013). Temperate and tropical zones present distinct thermal amplitudes during the year reflecting marked differences in their seasons. Hence, generalizations about synchronicity are not certain once there are doubts if sets of lakes existing in different regions operate similarly.

Here we address the issue of temporal coherence in tropical lakes. The objective of this work is to evidence and quantify the temporal coherence of different variables and lake pairs using data series produced by the Long-Term Ecological Research Program of the Rio Doce State Park - PERD of four lakes. We analyzed a suite of limnological variables to test the hypothesis of synchronicity both space and time. For that, two predictors of temporal coherence of lake pairs were also tested: proximity and exposure to climatic factors. Our tested lakes share the same geomorphological and weather contexts while varying significantly in morphometry, trophic states, size, and species composition being ideal systems to test the presence of temporal coherence.

The primary expectations of our work were: (i) presence of temporal coherence between the studied lakes considering the variables, pairs of lakes, and time series analyzed; (ii) stronger synchronicity for physical and chemical variables than for biological variables; (iii) stronger temporal coherence for pairs of lakes that are more similar in exposure to climatic factors; (iiii) stronger temporal coherence for pairs of lakes closest to each other.

\section{Material and Methods}

\subsection{Study area}

The State Park of Rio Doce-PERD is located in the middle course of the Rio Doce watershed in southeastern Brazil. It is a Conservation Unit comprising a complex lacustrine system of 42 lakes (Latini \& Petrere, 2004) - 14\% of the, approximately, 300 water bodies found in the region. Here, four lakes were analyzed: (1) Carioca, (2) Dom Helvécio, (3) Gambazinho, and (4) Jacaré. The first three located inside the park and the last on its surrounding (Figure 1).
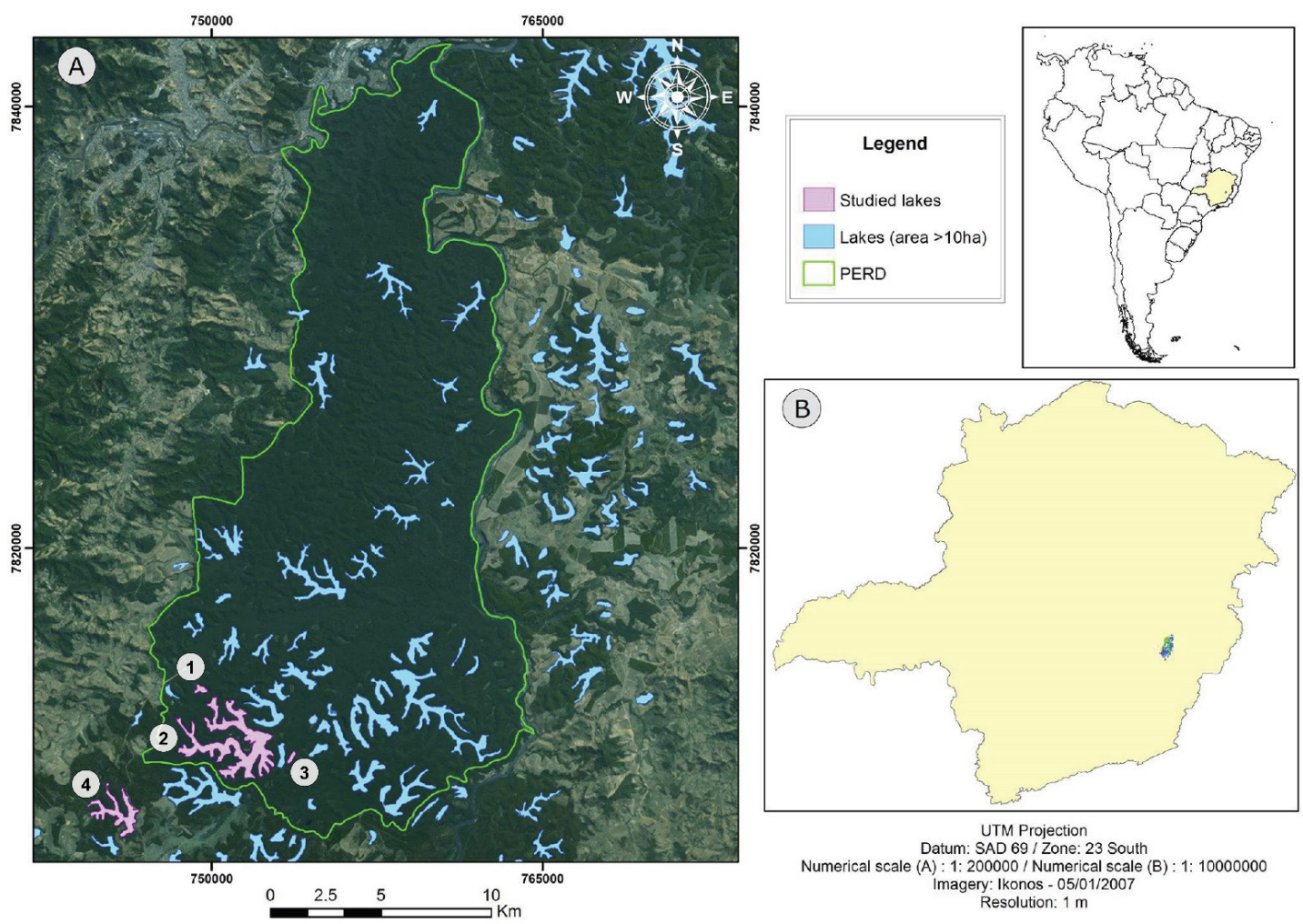

Figure 1. The spatial location of study area. (A) The Rio Doce State Park (PERD) and its surroundings. The lakes of the region with an area greater than 10 ha are represented in blue $(\mathrm{n} \simeq 300)$. Our analyzed lakes are shown in purple. They are numbered as (1) Carioca Lake; (2) Dom Helvécio Lake; (3) Gambazinho Lake; and (4) Jacaré Lake; (B) The location of our study site in the SE portion of the Minas Gerais state. 
The climate of the region is classified as humid subtropical (Nimer, 1989), with two distinct seasons: a wet season, with higher temperatures between October to March and a dry one, with cooler temperatures between April and September. The precipitation and mean monthly temperature of Ipatinga, located 40 kilometers from the studied lakes, exemplifies this pattern (Figure 2). The meteorological data were provided by the Integrated Environmental Data System (SINDA/INPE).

The (1) Carioca Lake is a small natural lake surrounded by Atlantic forest. This lake presents a surface area of $0.14 \mathrm{~km}^{2}$, a maximum depth of 11.8 meters, and a mean depth of 4.76 meters (Bezerra-Neto et al., 2010). It is a mesotrophic and warm-monomictic lake, with a short period of circulation during the winter (June to August) (Henry \& Barbosa, 1989).

The (2) Dom Helvécio Lake, is one of the largest and deepest natural lakes in Brazil (Tundisi \& Saijo, 1997). The lake shows a complex dendritic form, with a surface area of $5.27 \mathrm{~km}^{2}$, a maximum depth of 39.2 meters, and a mean depth of 11.3 meters (Bezerra-Neto \& Pinto-Coelho, 2008). It is classified as an oligo-mesotrophic and warm-monomictic lake, with a circulation period between May and August (Maia-Barbosa et al., 2010).
Moreover, the (3) Gambazinho Lake has a simple morphometry - similar to the Carioca Lake. The lake exhibits a surface area of $0.09 \mathrm{~km}^{2}$, a maximum depth of 10.3 meters, and a mean depth of 4.56 meters (Bezerra-Neto, not published data). Additionally, it is an oligotrophic and polimictic lake, with several thermal stratification events during the year.

Finally, the (4) Jacaré Lake is surrounded by a monoculture of Eucalyptus $s p$. besides minor domestic sewage entries in its waters from a local fisheries club. The lake displays a surface area of $1.2 \mathrm{~km}^{2}$, a maximum depth of 9.4 meters, and a mean depth of 3.6 meters (Bezerra-Neto, not published data). Furthermore, it is considered an oligo-mesotrophic and warm-monomictic lake (Brandão et al., 2012). Table 1 summarizes the above information.

\subsection{Variables and sampling}

Data of the lakes were obtained from the database of the Brazilian Long-Term Ecological Research Program (LTER) site 4 (PELD / CNPq) between 2004 and 2009. These six years were selected for presenting a more complete compilation of data compared with previous years. We analyzed nine limnological variables for synchronicity - including physical, chemical, and biological variables. Table 2 summarizes the used variables, their categories, and

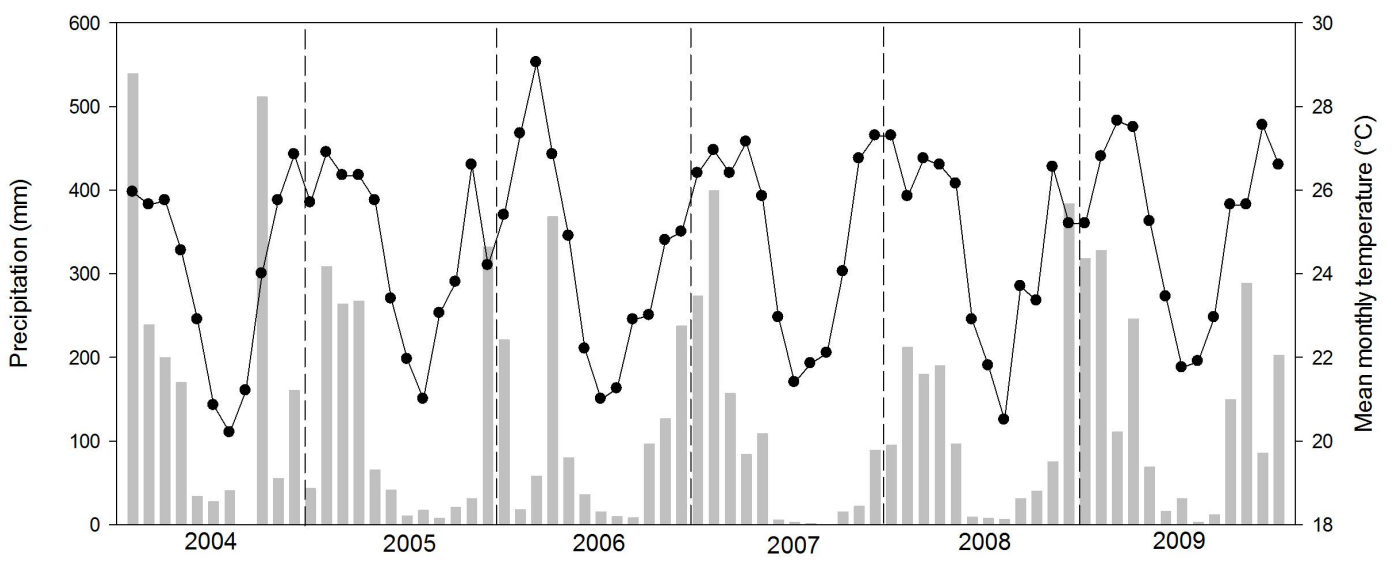

Figure 2. Climate Diagram of the region of Ipatinga between the years of 2004 to 2009.

Table 1. Characteristics of the four lakes selected for this study.

\begin{tabular}{lccclcccc}
\hline \multicolumn{1}{c}{ Lake } & Latitude & Longitude & $\begin{array}{c}\mathbf{A} \\
\left(\mathbf{K m}^{2}\right)\end{array}$ & Trophic status & $\begin{array}{c}\text { Zmax } \\
(\mathbf{m})\end{array}$ & $\begin{array}{c}\overline{\mathbf{z}} \\
(\mathbf{m})\end{array}$ & $\begin{array}{c}\text { Circulation } \\
\text { patterns }\end{array}$ & $\begin{array}{c}\mathbf{A}: \overline{\mathbf{z}} \\
(\mathbf{m \times 1 0})\end{array}$ \\
\hline Carioca & $19^{\circ} 45^{\prime} \mathrm{S}$ & $42^{\circ} 37^{\prime} \mathrm{W}$ & 0.14 & Mesotrophic & 11.8 & 4.76 & Warm- monomictic & 2.9 \\
Dom Helvécio & $19^{\circ} 46^{\prime} \mathrm{S}$ & $42^{\circ} 35^{\prime} \mathrm{W}$ & 5.27 & Oligo-mesotrophic & 39.2 & 11.3 & Warm-monomictic & 46.6 \\
Gambazinho & $19^{\circ} 47^{\prime} \mathrm{S}$ & $42^{\circ} 34^{\prime} \mathrm{W}$ & 0.09 & Oligotrophic & 10.3 & 4.56 & Polimictic & 2 \\
Jacaré & $19^{\circ} 48^{\prime} \mathrm{S}$ & $42^{\circ} 38^{\prime} \mathrm{W}$ & 1.20 & Oligo-mesotrophic & 9.4 & 3.6 & Warm-monomictic & 33.8 \\
\hline
\end{tabular}

Notes: Definitions are as follow: $\mathrm{A}=$ Surface area, $\mathrm{Zmax}=$ maximum depth, $\overline{\mathrm{z}}=$ mean depth; A: $\overline{\mathrm{z}}=$ surface area/ mean depth ratio. 
the length of record used in the temporal coherence analysis. The variables were selected according to (1) the availability in the database and (2) the presence of more complete time series.

The four lakes were sampled monthly at a fixed point in the limnetic region during 2004 and 2009. The data for temperature, $\mathrm{pH}$, and dissolved oxygen were obtained by profiles using multiparameter probe Horiba U22 (Enviro Equipament Inc.). For the other variables, the samples were collected at four different depths determined by Secchi disk. In both cases, only sub-surface data ( 0.5 meters) were considered.

In each lake, water samples were collected with a van Dorn bottle (3 liters) for analysis of total phosphorus (TP), total nitrogen (TN), dissolved organic carbon (DOC), colored dissolved organic carbon (CDOM), and chlorophyll-a (Chl-a). Unfiltered samples for TN and TP were frozen and analyzed in the laboratory following Mackereth et al. (1978) and Golterman et al. (1978).

Samples for Chl-a were filtered with Schleicher \& Schuell GF 52-C filters and analyzed using the extraction technique in acetone $90 \%$ according to Lorenzen (1967). For DOC and CDOM, the samples were filtered using $0.7 \mu \mathrm{m}$ filters (Whatman GF/F). The concentrations of DOC $\left(\mathrm{mg}^{\mathrm{L}} \mathrm{L}^{-1}\right)$ were determined by high-temperature catalytic oxidation method using the total carbon analyzer Shimadzu TOC 5000 (Shimadzu Inc.). The detection limit of the analysis process was $0.05 \mathrm{mgC} . \mathrm{L}^{-1}$. The spectrophotometric absorbance $\left(\mathrm{m}^{-1}\right)$ of CDOM in the water was determined with the spectrophotometer UV-1700 Shimadzu (Shimadzu Inc.), using quartz cuvettes of $5 \mathrm{~cm}$ and using Milli-Q water as the reference (blank).

Phytoplankton richness was accessed through the number of species identified by qualitative samplings, performed with vertical and horizontal throws using a $20 \mu \mathrm{m}$ mesh plankton net and fixed with $4 \%$ formaldehyde, as well as quantitative samplings, collected with Van Dorn bottles and fixed with lugol. Table 3 presents the descriptive statistics of the variables measured for the four lakes.

\subsection{The temporal coherence analysis}

For each variable, a matrix of month/lake was generated. Using these matrices, we calculated the Pearson correlation coefficient between all pairs of lakes $(\mathrm{N}=6)$ and performed the average to provide a measurement of the temporal coherence of the different variables and the distinct pairs of lakes. The level of temporal coherence was recognized as being the magnitude of the mean correlation.

Some assumptions should be tested in order to use time series as evidence of synchronicity, namely: randomized time series should display

Table 2. Physical, chemical and biological variables included in the study.

\begin{tabular}{llcc}
\hline Type of variable & \multicolumn{1}{c}{ Variable } & Units & Length of record (years) \\
\hline Physical & Water temperature & ${ }^{\circ} \mathrm{C}$ & 6 \\
& Dissolved organic carbon (DOC) & $\mathrm{mg} / \mathrm{L}$ & 4.5 \\
& Colored dissolved organic matter (CDOM) & $\mathrm{m}^{-1}$ & 3.5 \\
\multirow{3}{*}{ Chemical } & Dissolved oxygen & $\mathrm{mg} / \mathrm{L}$ & 6 \\
& $\mathrm{pH}$ & & 6 \\
& Total phosphorus & $\mu \mathrm{g} / \mathrm{L}$ & 4.5 \\
& Total nitrogen & $\mathrm{\mu g} / \mathrm{L}$ & 4.5 \\
\multirow{2}{*}{ Biological } & Chlorophyll-a & $\mathrm{\mu g} / \mathrm{L}$ & 6 \\
& Phytoplankton richness & & 4 \\
\hline
\end{tabular}

Table 3. Descriptive statistics of the limnological variables measured at Carioca, Dom Helvécio, Gambazinho, and Jacaré Lakes.

\begin{tabular}{|c|c|c|c|c|c|c|c|c|c|c|c|c|}
\hline \multirow{3}{*}{ Variable } & \multicolumn{12}{|c|}{ Lake } \\
\hline & \multicolumn{3}{|c|}{ Carioca } & \multicolumn{3}{|c|}{ Dom Helvécio } & \multicolumn{3}{|c|}{ Gambazinho } & \multicolumn{3}{|c|}{ Jacaré } \\
\hline & Mean & Range & $\mathbf{N}$ & Mean & Range & $\mathbf{N}$ & Mean & Range & $\mathbf{N}$ & Mean & Range & $\mathbf{N}$ \\
\hline Water temperature & 27.4 & $21.9-32$ & 71 & 28.1 & $23.5-31.8$ & 70 & 28.7 & $22.9-33$ & 72 & 27.6 & $22.4-32$ & 69 \\
\hline DOC & 6.3 & $6.0-12.0$ & 49 & 5.2 & $1.3-13.2$ & 49 & 4.6 & $2.2-11.5$ & 45 & 6.1 & 4.1 & 47 \\
\hline CDOM & 6.3 & $3.6-10.1$ & 38 & 3.1 & $1.3-5.8$ & 40 & 2.5 & $1.0-4.7$ & 39 & 4.3 & $2.4-8.8$ & 40 \\
\hline Dissolved oxygen & 8.6 & $1.3-20$ & 70 & 8.8 & $2.8-18.8$ & 70 & 8.1 & $2.2-11.7$ & 72 & 8.2 & $0.5-16.5$ & 71 \\
\hline $\mathrm{pH}$ & 6.2 & $4.6-9.8$ & 70 & 6.3 & $4.8-8.5$ & 70 & 6.1 & $2.6-9.5$ & 72 & 6.3 & $4.7-9.3$ & 71 \\
\hline Total phosphorus & 18 & $7.8-39.3$ & 52 & 15.4 & $5.5-41.3$ & 52 & 13.7 & $2.9-34.6$ & 51 & 19.5 & $6.8-50.1$ & 51 \\
\hline Total nitrogen & 432 & $48-1642.6$ & 52 & 408 & $95.5-914.5$ & 52 & 334 & $34.9-765.6$ & 53 & 400.9 & $51-1310.2$ & 51 \\
\hline Chlorophyll-a & 29.3 & $7-80.2$ & 68 & 14 & $0.8-31$ & 68 & 15.2 & $4.3-41.4$ & 69 & 16.3 & $5.9-37.4$ & 68 \\
\hline Phytoplankton richness & 24 & $7.0-37$ & 46 & 27 & $11.0-45$ & 47 & 10 & $4.0-35$ & 46 & 22 & $3.0-44$ & 44 \\
\hline
\end{tabular}


correlations centered on zero to support the null hypothesis; Pearson and Spearman correlations should generate similar results independently of the data distribution; the exclusion of the maximum values of the time series should not change the values of the correlations substantially (Caliman et al., 2010). All assumptions were tested, and we decided to present only the Pearson correlation values.

Additionally, we investigated the relationship between the synchronicity of the pairs of lakes and two possible predictors of temporal coherence: proximity and exposure to climatic factors. The spatial proximity of the lake pairs was calculated in kilometers considering the straight-line distance from one lake to the other. The exposure to climatic factors was estimated using two metrics: surface area and surface area/mean depth ratio, and for each lake pair, a 'between-site' difference was measured. The differences were standardized by attributing a unit value for the biggest number (Dom Helvécio Lake) and expressing the others lakes as decimal fractions of the group maximum; the 'between-site' differences were taken from the final numbers. Finally, the Pearson correlation coefficient was calculated between the temporal coherence of the pairs of lakes and each one of the predictors (e.g. George et al., 2000). The presence of normality and the absence of outliers were checked. All analyses were performed in R program (R Development Core Team, 2015).

\section{Results}

\subsection{Temporal coherence of the variables}

In the four lakes of the PERD, all variables varied through time both within and among the years exhibiting different interannual patterns and degrees of synchronicity as exemplified by three variables (water temperature, $\mathrm{pH}$, and chlorophyll-a, Figure 3). The average temporal
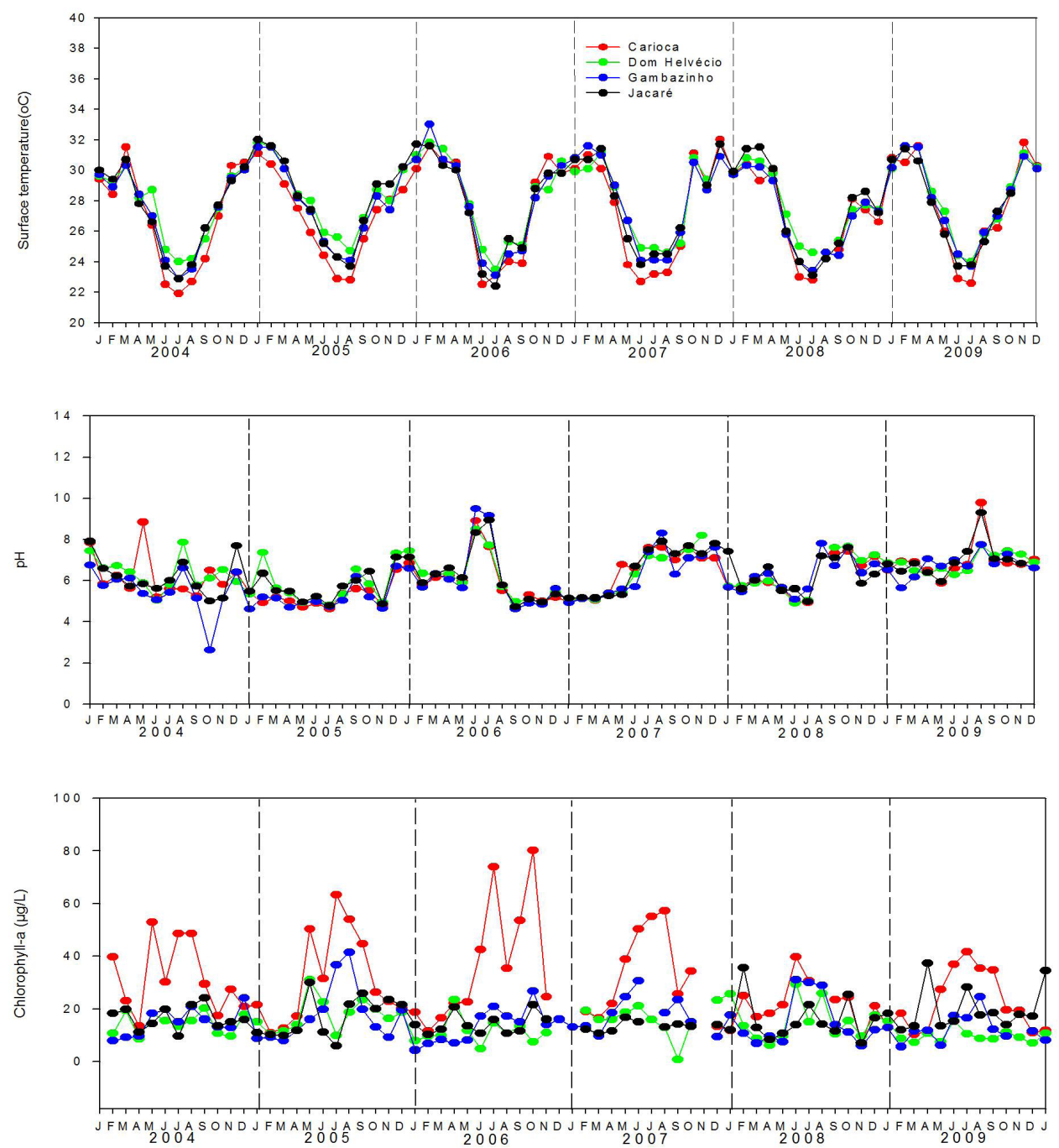

Figure 3. Time series of water temperature, $\mathrm{pH}$, and chlorophyll-a illustrating different degrees of temporal coherence. Notes: The synchronicity for the variables is: water temperature=0.97; $\mathrm{pH}=0.78$; chlorophyll- $\mathrm{a}=0.25$. 
coherence was 0.58 , considering all the variables and all pairs of lakes. The results showed considerable differences in the correlations between physical, chemical and biological variables (Figure 4). The largest value was recorded for water temperature (0.97) and the lowest for phytoplankton richness (-0.02). Overall, the physical and chemical variables presented stronger positive correlations compared with the biological ones.

Regarding individual correlations (Table 4), the variable 'water temperature' $(\mathrm{N}=67)$ presented the highest values, ranging from $0.96, \mathrm{p}<0.001$ (Carioca/ Dom Helvécio), to 0.98, p<0.001 (Dom Helvécio/ Gambazinho and Gambazinho/Jacaré).

Concerning the chemical variables, the parameter 'DOC' $(\mathrm{N}=38)$ exhibited moderate to high correlation values, from a minimum of $0.65, \mathrm{p}<0.001$ (Dom Helvécio/ Gambazinho) to a maximum of 0.79 , $\mathrm{p}<0.001$ (Carioca/Jacaré). The 'dissolved oxygen' $(\mathrm{N}=68)$ also showed moderate to high correlations,

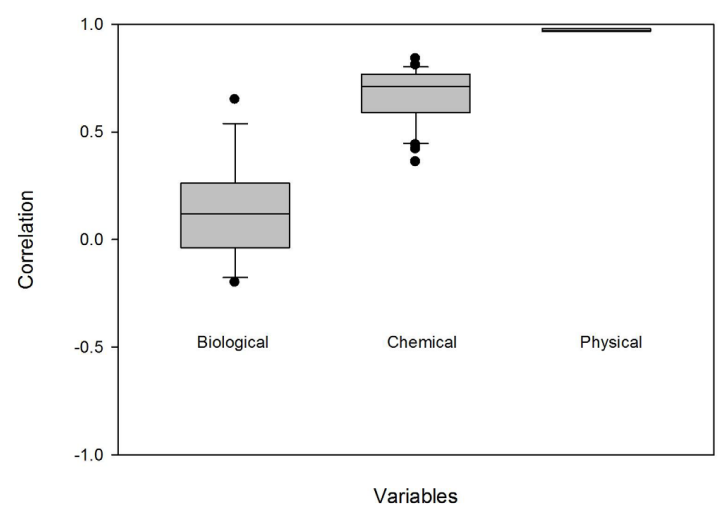

Figure 4. Distribution of correlation values for the physical, chemical, and biological variables studied. but with a greater amplitude of values from $0.59, \mathrm{p}<0.001$ (Carioca/Jacaré) to $0.84, \mathrm{p}<0.001$ (Carioca/Dom Helvécio). In contrast, the 'CDOM' $(\mathrm{N}=36)$ presented more moderate correlations varying from $0.44, \mathrm{p}<0.05$ (Gambazinho/Jacaré) to $0.73, \mathrm{p}<0.001$ (Carioca/Dom Helvécio). Additionally, the ' $\mathrm{pH}$ ' $(\mathrm{N}=68)$ presented correlations that fluctuated from a minimum of 0.72 , $\mathrm{p}<0.001$ (Carioca/Gambazinho) to a maximum of $0.84, \mathrm{p}<0.001$ (Gambazinho/Jacaré). The parameter 'total phosphorous' $(\mathrm{N}=47)$ presented correlations varying from $0.36, \mathrm{p}<0.05$ (Carioca/Jacaré) to 0.74, $\mathrm{p}<0.001$ (Dom Helvécio/Gambazinho), and the 'total nitrogen' ranged from 0.59 , $\mathrm{p}<0.001$ (Dom Helvécio/ Jacaré) to 0.77, $\mathrm{p}<0.001$ (Gambazinho/Jacaré).

The biological parameters 'chl-a' and 'phytoplankton richness', exhibited correlation values much lower than the physical and chemical variables, being often not significant (i.e. $\mathrm{p} \geq 0.05$ ). Only three pairs of lakes exhibited significant correlations for chl-a: Dom Helvécio/ Gambazinho $(\mathrm{r}=0.28, \mathrm{p}<0.05)$, Dom Helvécio/ Jacaré $(\mathrm{r}=0.24, \mathrm{p}<0.05)$ and Carioca/ Gambazinho $(\mathrm{r}=0.65, \mathrm{p}<0.001)$. For phytoplankton richness, none of the correlations were significant. From the correlations, the temporal coherence of each variable was calculated by average; their values are expressed in Table 5.

\subsection{Temporal coherence of the lake pairs}

The temporal coherence for the pairs of lakes is consistent for all the pairings, i.e. small amplitude of values. The pair 'Carioca/Gambazinho' had the highest temporal coherence value (0.63), followed by Dom Helvécio/Jacaré (0.61),

Table 4. Pearson correlation (r) of the different variables for each pair of lakes.

\begin{tabular}{|c|c|c|c|c|c|c|c|c|c|c|c|c|c|}
\hline \multirow{3}{*}{ Variable } & \multicolumn{12}{|c|}{ Pairs of lakes } & \multirow{3}{*}{$\mathbf{N}$} \\
\hline & \multicolumn{2}{|c|}{ Car/Dom } & \multicolumn{2}{|c|}{ Car/Gamb } & \multicolumn{2}{|c|}{ Car/Jac } & \multicolumn{2}{|c|}{ Dom/Gamb } & \multicolumn{2}{|c|}{ Dom/Jac } & \multicolumn{2}{|c|}{ Gamb/Jac } & \\
\hline & $r$ & $p$ & $\mathbf{r}$ & $p$ & $r$ & $p$ & $\mathbf{r}$ & $\mathbf{p}$ & $\mathbf{r}$ & $p$ & $r$ & $p$ & \\
\hline Water temperature & 0.96 & $<0.001$ & 0.97 & $<0.001$ & 0.97 & $<0.001$ & 0.98 & $<0.001$ & 0.97 & $<0.001$ & 0.98 & $<0.001$ & 67 \\
\hline DOC & 0.7 & $<0.001$ & 0.74 & $<0.001$ & 0.79 & $<0.001$ & 0.65 & $<0.001$ & 0.76 & $<0.001$ & 0.78 & $<0.001$ & 38 \\
\hline CDOM & 0.73 & $<0.001$ & 0.45 & $<0.05$ & 0.59 & $<0.001$ & 0.51 & $<0.05$ & 0.62 & $<0.001$ & 0.44 & $<0.05$ & 36 \\
\hline Dissolved oxygen & 0.84 & $<0.001$ & 0.64 & $<0.001$ & 0.59 & $<0.001$ & 0.8 & $<0.001$ & 0.76 & $<0.001$ & 0.77 & $<0.001$ & 68 \\
\hline $\mathrm{pH}$ & 0.75 & $<0.001$ & 0.72 & $<0.001$ & 0.79 & $<0.001$ & 0.77 & $<0.001$ & 0.81 & $<0.001$ & 0.84 & $<0.001$ & 68 \\
\hline Total phosphurus & 0.42 & $<0.05$ & 0.46 & $<0.05$ & 0.36 & $<0.05$ & 0.74 & $<0.001$ & 0.54 & $<0.001$ & 0.58 & $<0.001$ & 47 \\
\hline Total nitrogen & 0.62 & $<0.001$ & 0.76 & $<0.001$ & 0.65 & $<0.001$ & 0.7 & $<0.001$ & 0.59 & $<0.001$ & 0.77 & $<0.001$ & 50 \\
\hline Chlorophyll-a & 0.15 & NS & 0.65 & $<0.001$ & 0.09 & NS & 0.28 & $<0.05$ & 0.24 & $<0.05$ & 0.07 & NS & 66 \\
\hline $\begin{array}{l}\text { Phytoplankton } \\
\text { richness }\end{array}$ & -0.12 & NS & .27 & NS & 0 & NS & -0.05 & NS & 0 & NS & -0.2 & NS & 39 \\
\hline
\end{tabular}

Notes: Definitions are as follow: $\mathrm{p}=$ probability; $\mathrm{N}=$ number of samples; $\mathrm{NS}=$ not significant. Pairs of lakes: Car/Dom: Carioca/ Dom Helvécio; Car/Gamb: Carioca/ Gambazinho; Car/Jac: Carioca/Jacaré; Dom/Gamb: Dom Helvécio/ Gambazinho; Dom/Jac: Dom Helvécio/ Jacaré; Gamb/Jac; Gambazinho/Jacaré. 
Table 5. Temporal coherence recorded for the different variables.

\begin{tabular}{lc}
\hline \multicolumn{1}{c}{ Variable } & Temporal coherence \\
\hline Water temperature & 0.97 \\
$\mathrm{pH}$ & 0.78 \\
DOC & 0.74 \\
Dissolved oxygen & 0.73 \\
TN & 0.68 \\
CDOM & 0.56 \\
TP & 0.52 \\
Chl-a & 0.25 \\
Phytoplankton richness & -0.02 \\
\hline
\end{tabular}

Table 6. Temporal coherence recorded for the lake pairs.

\begin{tabular}{lc}
\hline \multicolumn{1}{c}{ Pairs of lake } & $\begin{array}{c}\text { Temporal } \\
\text { coherence }\end{array}$ \\
\hline Carioca - Gambazinho & 0.63 \\
Dom Helvécio - Jacaré & 0.61 \\
Dom Helvécio - Gambazinho & 0.60 \\
Carioca - Dom Helvécio & 0.56 \\
Gambazinho - Jacaré & 0.56 \\
Carioca - Jacaré & 0.54 \\
\hline
\end{tabular}

Dom Helvécio/Gambazinho (0.60), Carioca/ Dom Helvécio (0.56), Gambazinho/Jacaré (0.56), and Carioca/Jacaré (0.54) (Table 6).

\subsection{Predictors of temporal coherence}

The geographical distance of each lake pair was 6.2 kilometers $(\mathrm{km})$ for Carioca/Gambazinho, $6.5 \mathrm{~km}$ for Dom Helvécio/Jacaré, $1.7 \mathrm{~km}$ for Dom Helvécio/ Gambazinho, $3.6 \mathrm{~km}$ for Carioca/DomHelvécio,7.9kmforGambazinho/Jacaré, and 6.7 for Carioca/Jacaré. No significant correlation was found between the distance of the lake pairs and their temporal coherences (-0.37, $\mathrm{p}>0.05)$. Additionally, considering the exposure to climatic factors, the temporal coherence values did not present a significant correlation with the standardized differences of the surface areas $(r=-0.05, \mathrm{p}>0.05)$ and the surface area/mean depth ratios $(r=-0.59, \mathrm{p}>0.05)$. Nevertheless, a moderate negative trend can be noticed.

\section{Discussion}

This study was based on a time scale of approximately six years and considered a maximum of 70 observations per lake, according to the variable analyzed. The average temporal coherence between the four lakes of the Rio Doce State Park was 'low' (0.58) taking into account a set of physical, chemical, and biological variables. Such value was lower than expected, considering that the analyzed lakes share the same geomorphological context (Pflug, 1969), and climatic conditions. The explanation for the temporal coherence found may be associated with the length of record used in the analysis. Lower time scales can underestimate the evaluation of the temporal coherence compared with larger time scales (Baines et al., 2000). Furthermore, coherence analysis is influenced by the number and types of variables included in the study (Magnuson et al., 2006). In our case, we selected a set of nine limnological variables, most being chemical ones. Thus, the results should be interpreted carefully.

Overall, the synchronicity patterns between the lakes Carioca, Dom Helvécio, Gambazinho, and Jacaré were similar to those found in temperate lakes (Magnuson et al., 1990; Kratz et al., 1998; Baines et al., 2000; Benson et al., 2000; George et al., 2000; Arnott et al., 2003) as well as in other tropical lakes (Caliman et al., 2010). In all the cases, the physical variables showed higher temporal coherence rates than the chemical variables, and the latter presented higher coherence values than the biological variables.

Regarding the individual parameters, we expected that some variables would present a higher synchronicity, e.g. water temperature, which showed to be highly coherent in studies made in temperate and boreal lakes (Baines et al., 2000; Benson et al., 2000; Arnott et al., 2003). Benson et al. (2000), studying the temporal coherence of the water temperature in different depths and different lake districts, found a high similarity in the patterns of the surface and epilimnetic temperature of the lakes. Therefore, a significant portion of the climatic signal would be transmitted to the upper layers of lakes (Benson et al., 2000). Nevertheless, the temporal coherence for 'water temperature' found here (0.97) was higher than expected, given the lower annual thermal amplitude experienced by tropical lakes compared to temperate systems (Caliman et al., 2010).

Several studies have indicated a strong connection between some chemical variables and climatic factors (e.g. Magnuson et al., 1990; Kratz et al., 1998; Arnott et al., 2003; Folster et al., 2005; Palmer et al., 2014). Hence, the moderate to high values of temporal coherence of ' $\mathrm{pH}$ ' $(0.78)$ and 'dissolved oxygen' (0.73) were not surprising. The former could be explained by the levels of carbon dioxide present in the atmospheric air and its equilibrium with the lacustrine environments. The latter could be an expression of the natural gas exchanges between water bodies and the 
atmosphere, the action of winds causing turbulences at the layers of air present above the lakes, and indirectly the solar radiation. Biotic influences are known to lower the temporal coherence of ' $\mathrm{pH}$ ' and 'dissolved oxygen'. Changes in the photosynthetic activities in the lake systems continually modify the values of dissolved oxygen and carbon dioxide in waters. One possible explanation for the low expression of the biotic influence on our results would be the moderate phytoplankton productivity present in the lakes of PERD (e.g. Tundisi \& Saijo, $1997)$ and the use of subsurface data (0.5 meters).

Remarkably, we found a moderate to high synchronicity for 'DOC' $(0.74)$, even without a direct hydrological connection between the lakes. Our results support the current understanding that climatic factors have a great role in the regional dynamics of carbon in lake districts (e.g. Kling et al., 2000; Pace \& Cole, 2002; Zhang et al., 2010). Probably, the allochthonous 'DOC' is considerably influenced by regional rainfalls, which export organic carbon to the lakes. In opposition, the autochthonous 'DOC' is produced by the primary producers of the systems being, possibly, one of the main intrinsic influences of dissimilarities. The parameter 'CDOM', i.e. the 'DOC' fraction that absorbs light in the ultraviolet and visible range (Kirk, 1994), presented a lower temporal coherence (0.56). The 'CDOM' concentration influence the availability of light and heat in the aquatic environment, hence affecting the thermal structure of lakes, which may change the dynamics of similarity. This result suggests that the factors that control the variability of CDOM and DOC are different despite the proximity of the lakes. The total solar radiation can be the defining climatic factor of the synchronic fraction of 'CDOM', due to its important action in the photobleaching process in lakes (Moran \& Zepp, 1997). However, our analyses indicate that the intrinsic factors are the main responsible for the patterns of this variable.

The temporal coherence values for nutrients, i.e. $\mathrm{TN}$ and TP (0.68 and 0.52, respectively) were similar to the average correlations found in previous studies in lake districts of temperate regions (Soranno et al., 1999; George et al., 2000). In contrast, our results are contradictory with the very low coherence values for nutrients and carbon for the northern Wisconsin lakes (Kratz et al., 1998). Kratz et al. (1998) justified such low coherence values by the minor importance of runoff to their studied lakes.

The biological variables, 'chl-a' and 'phytoplankton richness', presented low values of temporal coherence (0.25 and -0.02 , respectively). Such low values were expected as phytoplankton dynamics of near lacustrine systems are disconnected, because intrinsic factors act locally (Baines et al., 2000). Furthermore, chlorophyll-a represents an indirect measurement of the concentration of phytoplankton present in a lake, which also explains the low values found. However, we found an individual exception, i.e. evidence of moderate similarities between the lakes Carioca and Gambazinho for chl-a $(r=0.65, p<0.001)$.

Considering the lakes Carioca and Gambazinho, both differ in their trophic states as well as in their circulation patterns, despite showing similar morphometrics. Additionally, the two lakes present distinct top predators and trophic chains, influencing in different ways the history of the phytoplankton biomass of these two systems (Pinto-Coelho et al., 2008). The Carioca Lake has exotic species of piscivorous fish, a significant development of invertebrate predators (Chaoboridae larvae), and a higher biomass concentration of primary producers, probably resulting from an inverted trophic cascade' (Pinto-Coelho et al., 2008). In contrast, the Gambazinho Lake has no exotic fish and this pattern for the food chain does not apply. Even with the potential importance of local factors for the control of biological variables, our results show that climate factors should not be ignored. The shared variations between lakes Carioca and Gambazinho for chl-a suggest the presence of common regional controls. Kent et al. (2007) pointed out that the existence of simple food chains in lakes may assist in the lower obscuration of the climate signal for biotic parameters. In the case of the two lakes highlighted, although the top predators are different, both have simple food chains with a small number of fish species and a low variety of phytoplankton and zooplankton communities (Pinto-Coelho et al., 2008). Nevertheless, it is possible that some local drivers are strongly influenced by regional signals, especially considering subsurface data. An example would be the concentration of nutrients controlled by precipitation and verified by Baines et al. (2000) as essential for the interannual dynamics of chl-a in their study area.

Ranking the temporal coherence values in decreasing order, the pairs seem to follow the expectations considering the exposure to climatic factors: higher values between lakes with similar sizes (Carioca/ Gambazinho and Dom Helvécio/ Jacaré) and lower between lakes with more distinct sizes (Carioca/ Jacaré and Gambazinho/ Jacaré). However, our results showed a small amplitude 
of values. The absence of significant correlations between the temporal coherences of the lake pairs and predictors may be a reflection of this resembling values. Our results differ from others studies that evidenced a clear negative relationship between distance and synchronicity (Kling et al., 2000; Lansac-Tôha et al., 2008), and between exposure to climatic factors and synchronicity (Magnuson et al., 1990; Kratz et al., 1998; George et al., 2000). However, the set of lakes used in this study present unique characteristics: the lakes closest to each other (Dom Helvécio / Gambazinho and Dom Helvécio / Carioca) are the ones that show the greatest differences in size, and the lakes farthest from each other (Gambazinho / Jacaré and Carioca / Jacaré) also present large differences in their dimensions. The two predictors analyzed seem to mix their influences on the four lakes losing strength individually, not having one that imposes a stronger pattern. This may explain why no clear spatial pattern were found for the lake pairs in our work.

\section{Conclusions}

The four tropical lakes analyzed showed common behavioral patterns considering both variables and pairs of lakes. As predicted, physical and chemical variables presented stronger synchronicities when compared to biological variables. Nevertheless, the temporal coherence of the lake pairs was not correlated with the spatial proximity and the exposure to climatic factors. The present work did not use several years of data or an expressive set of lakes. Thus, generalizations are still difficult. Further investigations are needed to determine which extrinsic factors are more relevant about the variables analyzed. Moreover, it is essential to determine if our results are consistent when considering a higher number of parameters, larger temporal/ spatial scales, and different water depths. The patterns found are close to those present in temperate regions and are essential to increase the understanding about the synchronic behavior of lake systems in different environments, by including more data from tropical regions. We need to expand our knowledge about the dynamics of tropical aquatic ecosystems at the landscape level, especially considering the context of climate change. For this, we reiterate the importance of an effort to reanalyze data series produced from long-term monitoring programs especially in tropical areas.

\section{Acknowledgements}

The authors would like to thank all the members of the Rio Doce State Park for logistic support; Daniel Peifer for the map of the study area and for the English revision; FAPEMIG/PELD (Process 21760) and PELD/CNPq (Process 403698/2012-0) for the financial support.

\section{References}

ARNOTT, S.E., KELlER, B., DILlON, P.J., YAN, N., PATERSON, M. and FINDLAY, D. Using temporal coherence to determine the response to climate change in boreal shield lakes. Environmental Monitoring and Assessment, 2003, 88(1-3), 365-388. PMid:14570423. http://dx.doi. org/10.1023/A:1025537628078.

BAINES, S.B., WEBSTER, K.E., KRATZ, T.K., CARPENTER, S.R. and MAGNUSON, J.J. Synchronous behavior of temperature, calcium, and chlorohphyll in lakes of northern Wisconsin. Ecology, 2000, 81(3), 815-825. http://dx.doi. org/10.1890/0012-9658(2000)081[0815:SBOTC A]2.0.CO;2.

BENSON, B.J., LENTERS, J.D., MAGNUSON, J.J., STUBBS, M., KRATZ, T.K., DILLON, P.J., HECKY, R.E. and LATHROP, R.C. Regional coherence of climatic and lake thermal variables of four lake districts in the Upper Great Lakes Region of North America. Freshwater Biology, 2000, 43(3), 517-527. http://dx.doi.org/10.1046/j.13652427.2000.00572.x.

BEZERRA-NETO, J.F. and PINTO-COELHO, R. Morphometric study of Lake Dom Helvécio, Parque Estadual do Rio Doce (PERD), Minas Gerais, Brazil: a re-evaluation. Acta Limnologica Brasiliensia, 2008, 20(2), 117-130.

BEZERRA-NETO, J.F., BRIGUENTI, L.S. and PINTO-COELHO, R.M. A new morphometric study of Carioca Lake, Parque Estadual do Rio Doce (PERD), Minas Gerais State, Brazil. Acta Scientiarum. Biological Sciences, 2010, 32(1), 49-54. http://dx.doi. org/10.4025/actascibiolsci.v32i1.4990.

BRANDÃO, L.P.M., FAJARDO, T., ESKINAZISANT'ANNA, E., BRITO, S. and MAIABARBOSA, P. Fluctuations of the population of Daphnia laevis Birge 1878: a six-year study in a tropical lake. Brazilian Journal of Biology $=$ Revista Brasileira de Biologia, 2012, 72(3), 479-487. http:// dx.doi.org/10.1590/S1519-69842012000300010.

CALIMAN, A., CARNEIRO, L.S., SANTANGELO, J.M., GUARIENTO, R.D., PIRES, A.P.F., SUHETT, A.L., QUESADO, L.B., SCOFIELD, V., FONTE, E.S., LOPES, P.M., SANCHES, L.F., AZEVEDO, F.D., MARINHO, C.C., BOZELLI, R.L., ESTEVES, F.A. and FARJALLA, V.F. Temporal coherence among tropical coastal lagoons: a search 
for patterns and mechanisms. Brazilian Journal of Biology $=$ Revista Brasileira de Biologia, 2010, 70(3, Suppl), 803-814. PMid:21085785. http://dx.doi. org/10.1590/S1519-69842010000400011.

CARNEIRO, L.S., CALIMAN, A., GUARIENTO, R.D., ROCHA, A.D.M., QUESADO, L.B., FONTE, E.S., SANTANGELO, J.M., LEAL, J.J.F., LOPES, P.M., MEIRELLES-PEREIRA, F., ESTEVES, F.A. and BOZELLI, R.L. Effects of food web structure and resource subsidies on the patterns and mechanisms of temporal coherence in a tropical coastal lagoon: an experimental mesocosm approach. Acta Limnologica Brasiliensia, 2013, 25(3), 315-325. http://dx.doi.org/10.1590/S2179975X2013000300010.

FÖLSTER, J., GORANSSON, E., JOHANSSON, $\mathrm{K}$. and WILANDER, A. Synchronous variation in water chemistry for 80 lakes in Southern Sweden. Environmental Monitoring and Assessment, 2005, 102(1-3), 389-403. PMid:15869198. http://dx.doi. org/10.1007/s10661-005-6394-7.

FÖLSTER, J., JOHNSON, R.K., FUTTER, M.N. and WILANDER, A. The Swedish monitoring of surface waters: 50 years of adaptive monitoring. Ambio, 2014, 43(Suppl 1), 3-18. PMid:25403966. http:// dx.doi.org/10.1007/s13280-014-0558-z.

GEORGE, D.G., TALLING, J.F. and RIGG, E. Factors influencing the temporal coherence of five lakes in the English Lake District. Freshwater Biology, 2000, 43(3), 449-461. http://dx.doi.org/10.1046/j.13652427.2000.00566.x.

GOLTERMAN, H.L., CLYMO, R.S. and OHNSTAD, M.A.M. Methods for physical and chemical analysis of fresh water. Oxford: Blackwell Scientific Publishing, 1978.

HENRY, R. and BARBOSA, F.A.R. Thermal structure, heat content and stability of two lakes in The National Park of Rio Doce Valley (Minas Gerais, Brazil). Hydrobiologia, 1989, 171(3), 189-199. http:// dx.doi.org/10.1007/BF00008142.

KENT, A.D., YANNARELL, A.C., RUSAK, J.A., TRIPLETT, E.W. and MCMAHON, K.D. Synchrony in aquatic microbial community dynamics. The ISME Journal, 2007, 1(1), 38-47. PMid:18043612. http://dx.doi.org/10.1038/ ismej.2007.6.

KIRK, J.T.O. Light and photosynthesis in aquatic ecosystems. 2nd ed. Cambridge: Cambridge University Press, 1994.

KLING, G.W., KIPPHUT, G.W., MILLER, M.M. and O'BRIEN, W.J. Integration of lakes and streams in a landscape perspective: the importance of material processing on spatial patterns and temporal coherence. Freshwater Biology, 2000, 43(3), 477-497. http://dx.doi.org/10.1046/j.13652427.2000.00515.x.
KRATZ, T.K., SORANNO, P.A., BAINES, S.B. BENSON, B.J., MAGNUSON, J.J., FROST, T.M. and LATHROP, R.C. Interannual synchronous dynamics in north temperate lakes in Wisconsin, USA. In: D.G. GEORGE, J.G. JONES, P. PUNCOCHAR, C.S. REYNOLDS and W.H. SUTCLIFFE, eds. Management of lakes and reservoirs during global climate change. Dordrecht: Kluwer, 1998, pp. 273-287.

LANSAC-TÔHA, F.A., BINI, L.M., VELHO, L.F.M., BONECKER, C.C., TAKAHASHI, E.M. and VIEIRA, L.C.G. Temporal coherence of zooplankton abundance in a tropical reservoir. Hydrobiologia, 2008, 614(1), 387-399. http://dx.doi.org/10.1007/ s10750-008-9526-6.

LATINI, A.O. and PETRERE, M. Reduction of native fish fauna by alien species: an example from Brazilian freshwater tropical lakes. Fisheries Management and Ecology, 2004, 11(2), 71-79. http://dx.doi. org/10.1046/j.1365-2400.2003.00372.x.

LIVINGSTONE, D.M., ADRIAN, R., ARVOLA, L., BLENCKNER, T., DOKULIL, M.T., HARI, R.E., GEORGE, G., JANKOWSKI, T., JARVINEN, M., JENNINGS, E., NÓGES, P., NÓSGES, T., STRAILE, D. and WEYHENMEYER, G.A. Regional and supra-regional coherence in limnological variables. In: D.G. GEORGE, ed. The impact of climate change on european lakes. Netherlands: Springer, 2010, pp. 311-337. Aquatic Ecology Series, vol. 4.

LORENZEN, C.J. Determination of chlorophyll and phaeopigments: spectrophotometric equation. Limnology and Oceanography, 1967, 12(2), 343-346. http://dx.doi.org/10.4319/lo.1967.12.2.0343.

MACKERETH, F.Y.H., HERON, J. and TALLING, J.F. Water analysis: some revised methods for limnologists. Ambleside: Freshwater Biological Association, 1978, 120 p. vol. 36.

MAGNUSON, J.J., BENSON, B.J. and KRATZ, T.K. Temporal coherence in the limnology of a suite of lakes in Wisconsin, U.S.A. Freshwater Biology, 1990, 23(1), 145-159. http://dx.doi. org/10.1111/j.1365-2427.1990.tb00259.x.

MAGNUSON, J.J., BENSON, B.J. and KRATZ, T.K. Patterns of coherent dynamics within and between lake districts at local to intercontinental scales. Boreal Environment Research, 2004, 9(5), 359-369.

MAGNUSON, J.J., KRATZ, T.K., BENSON, B.J. and WEBSTER, K.E. Coherence dynamics among lakes. In: J.J. MAGNUSON, T.K. KRATZ and B.J. BENSON, eds. Long-term dynamics of lakes in the landscape. USA: Oxford University Press, 2006, pp. 89-106. vol. 1.

MAIA-BARBOSA, P.M., BARBOSA, L.G., BRITO, S.L., GARCIA, F., BARROS, C.F.A., SOUZA, M.B.G., MELLO, N., GUIMARÁES, A.S. and BARBOSA, F.A.R. Limnological changes in Dom 
Helvécio Lake (South-East Brazil): natural and anthropogenic causes. Brazilian Journal of Biology = Revista Brasileira de Biologia, 2010, 70(3, Suppl), 795802. PMid:21085784. http://dx.doi.org/10.1590/ S1519-69842010000400010.

MORAN, M.A. and ZEPP, R.G. Role of photoreactions in the formation of biologically labile compounds from dissolved organic matter. Limnology and Oceanography, 1997, 42(6), 1307-1316. http:// dx.doi.org/10.4319/lo.1997.42.6.1307.

NIMER, E. Climatologia do Brasil. Rio de Janeiro: IBGE, 1989.

PACE, M.L. and COLE, J.J. Synchronous variation of dissolved organic carbon and color in lakes. Limnology and Oceanography, 2002, 47(2), 333-342. http:// dx.doi.org/10.4319/lo.2002.47.2.0333.

PALMER, M.E., YAN, N.D. and SOMERS, K.M. Climate change drives coherent trends in physics and oxygen content in North American lakes. Climatic Change, 2014, 124(1-2), 285-299. http://dx.doi. org/10.1007/s10584-014-1085-4.

PFLUG, R. Quaternary lakes of eastern Brazil. Photogrammetria, 1969, 24(1), 29-35. http://dx.doi. org/10.1016/0031-8663(69)90029-5.

PINTO-COELHO, R.M., BEZERRA-NETO, J.F., MIRANDA, F., MOTA, T.G., RESCK, R., SANTOS, A.M., MAIA-BARBOSA, P.M., MELLO, N.A.S.T., MARQUES, M.M., CAMPOS, M.O. and BARBOSA, F.A.R. The inverted trophic cascade in tropical plankton communities: impacts of exotic fish in the Middle Rio Doce lake district, Minas Gerais, Brazil. Brazilian Journal of Biology $=$ Revista
Brasileira de Biologia, 2008, 68(4, Suppl), 1025-1037. PMid:19197473. http://dx.doi.org/10.1590/S151969842008000500010.

R DEVELOPMENT CORE TEAM. $R$ : a language and environment for statistical computing [software]. Vienna: R Foundation for Statistical Computing, 2015. [viewed 10 Oct. 2016]. Available from: https:// www.R-project.org/

SORANNO, P.A., WEBSTER, K.E., RIERA, J.L., KRATZ, T.K., BARON, J.S., BUKAVECKAS, P.A., KLING, G.W., WHITE, D.S., CAINE, N., LATHROP, R.C. and LEAVITT, P.R. Spatial variation among lakes within landscapes: Ecological organization along lake chains. Ecosystems (New York, N.Y.), 1999, 2(5), 395-410. http://dx.doi. org/10.1007/s100219900089.

TUNDISI, J.G. and SAIJO, Y. Limnological studies on the Rio Doce Valley Lakes, Brazil. São Carlos: Academy of Sciences, University of São Paulo, School of Engineering at Sáo Carlos, Center for Water Resources and Applied Ecology, 1997.

ZHANG, J., HUDSON, J., NEAL, R., SEREDA, J., CLAIR, T., TURNER, M., JEFFRIES, D., DILLON, P., MOLOT, L., SOMERS, K. and HESSLEIN, R. Long-term patterns of dissolved organic carbon in lakes across eastern Canada: Evidence of a pronounced climate effect. Limnology and Oceanography, 2010, 55(1), 30-42. http://dx.doi. org/10.4319/lo.2010.55.1.0030.

Received: 10 October 2016 Accepted: 21 August 2017 